\title{
Pengaruh Kepemimpinan, Kompensasi Dan Laba Pada Kepuasan Kerja Karyawan PT. Bank Bukopin Tbk. Cabang Denpasar
}

\author{
Made Dwi Pradipta Utama ${ }^{1}$ \\ Fakultas Ekonomi dan Bisnis \\ Universitas Udayana, Indonesia. \\ Email: dipta_utama1316@yahoo.com
}

\author{
Maria M. Ratna Sari² \\ Fakultas Ekonomi dan Bisnis \\ Universitas Udayana, Indonesia.
}

\begin{abstract}
ABSTRAK
Kepuasan kerja merupakan sikap positif individu secara umum terhadap pekerjaannya. Agar pegawai memiliki kepuasan kerja yang tinggi, suatu organisasi perlu memperhatikan faktor - faktor yang mempengaruhi kepuasan kerja. Tujuan Penelitian adalah untuk mengetahui pengaruh kepemimpinan dan kompensasi terhadap kepuasan kerja karyawan. Selain itu juga untuk mengetahui pengaruh yang lebih besar atau kuat dari kedua variabel tersebut terhadap kepuasan kerja karyawan.Penelitian ini dilakukan di PT. Bank Bukopin (Persero) Tbk. Cabang Denpasar. Jumlah sampel yang diambil sebanyak 89 orang karyawan dengan metode pengumpulan data dilakukan dengan menggunakan kuesioner.

Kata Kunci : $\quad$ Pengaruh Kepemimpinan; Kompensasi; Laba; Kepuasan Kerja.

The Influence Of Leadership, Compensation And Profits On Employee Job Satisfaction PT. Bank Bukopin Tbk. Branch Denpasar
\end{abstract}

\section{ABSTRACT}

Job satisfaction is an individual positive attitude in general towards his/her job. In order for the employee to have high job satisfaction, an organization needs to take attention factors which influencing job satisfaction. The research aims to find out the impact of leadership and compensation towards employee's job satisfaction. In addition also to find out the bigger or stronger impact from both variables towards employee's job satisfaction. The research was conducted at PT. Bank Bukopin (Persero) Tbk. branch of Denpasar. Amount of sample taken was 89 employees with data collection method was carried out by using questionnaire.

Keywords: Impact of Leadership; Compensation; Profit; Job Satisfaction.

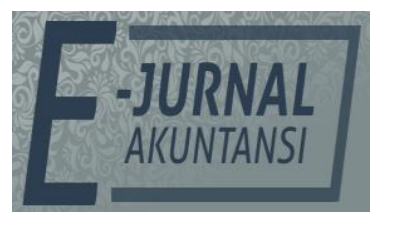

E-JA

e-Jurnal Akuntansi e-ISSN 2302-8556

Vol.298 No. 1 Denpasar, Oktober 2019

Hal. 437-450

Artikel masuk: 05 Juni 2019

Tanggal diterima: 02 Oktober 2019 


\section{PENDAHULUAN}

Sukses tidaknya suatu organisasi sangat tergantung dari kualitas sumber daya manusia yang dimiliki karena sumber daya manusia yang berkualitas adalah sumber daya manusia yang mampu berprestasi maksimal. Kepuasan kerja mempunyai peranan penting terhadap prestasi kerja karyawan, ketika seorang karyawan merasakan kepuasan dalam bekerja maka seorang karyawan akan berupaya semaksimal mungkin dengan segenap kemampuan yang dinilai untuk menyelesaikan yang akhirnya akan menghasilkan kinerja dan pencapaian yang baik bagi perusahaan.

Kepuasan kerja adalah suatu perasaan positif tentang pekerjaan seseorang yang merupakan hasil dari sebuah evaluasi karakteristiknya Robbins (2009). Kepuasan kerja yang rendah akan menimbulkan beberapa dampak yang negatif seperti mangkir kerja, mogok kerja, kerja lamban, pindah kerja, dan kerusakan yang disengaja. Sebaliknya kepuasan kerja tinggi sangat mempengaruhi kehadiran dan perputaran karyawan yang lebih baik, karyawan memiliki prestasi kerja dan kinerja yang lebih baik.Ditinjau dari pemberdayaan dan pengelola SDM perusahaan perlu menciptakan lingkungan yang kondusif, imbalan yang layak dan adil, beban kerja yang sesuai dengan keahlian karyawan, sikap perilaku dari manajer atau atasan untuk membentuk kepuasan kerja karyawan karyawan menjadi penting karena merupakan salah satu kunci pendorong disiplin serta kinerja karyawan yang akan berpengaruh terhadap kualitas pelayanan.

Menurut Hasibuan (2007) faktor-faktor yang dapat mempengaruhi kepuasan kerja adalah balas jasa adil adil dan layak, penempatan kerja yang sesuai dengan keahlian, berat ringannya keahlian, suasana dan lingkungan pekerjaan, peralatan yang menunjang pekerjaan, sikap kepemimpinan dalam kepemimpinannya dan sikap pekerja yang monoton atau tidak.. Kerja yang secara mental menantang dalam artian karyawan cenderung menyukai pekerjaan-pekerjaan yang memberi mereka kesempatan untuk menggunakan keterampilan. Ganjaran yang pantas yaitu berupa kompensasi yang adil dan sesuai dengan harapan-harapan karyawan sehingga dapat menimbulkan kepuasan.Kondisi yang mendukung yaitu berkaitan dengan kenyamanan kerja.Rekan kerja yang mendukung, dalam hal ini adalah hubungan harmonis yang berjalan baik antar sesama karyawan dengan tuntunan dari pekerjaan yang diemban karyawan.

Teori kepemimpinan pada umumnya berusaha untuk memberikan penjelasan dan interpretasi mengenai pemimpin dan kepemimpinan dengan mengemukakan beberapa segi antara lain latar belakang sejarah pemimpin dan kepemimpinan. Semakin baik kepemimpinan maka kepuasan karyawan akan meningkat. Menurut Grimes (2003) pemimpin berperan dalam meningkatkan kemampuan, komitmen, keterampilan pemahaman nilai-nilai pada organisasi serta kerjasama tim untuk memperbaiki kinerja dalam organisasi apabila pimpinan mampu menerapkan kepemimpinan yang tepat, maka karyawan akan merasa puas yang pada akhirnya mampu memperbaiki kinerjanya.Pemimpin pada hakikatnya adalah seorang yang mempunyai kemampuan untuk mempengaruhi perilaku orang lain di dalam kerjanya dengan menggunakan kekuasaan. Kekuasaan merupakan kemampuan untuk mengarahkan dan 
mempengaruhi bawahan sehubungan dengan tugas tugas yang harus di laksanaknnya. Semakin banyak jumlah sumber kekuasaan yang tersedia bagi pemimpin,akan semakin besar potensi kepemimpinan yang efektif. Samsudin (2005) menyatakan Motivasi merupakan satu penggerak dari dalam hati seseorang untuk melakukan atau mencapai suatu tujuan. motivasi juga bisa dikatakan sebagai rencana atau keinginan untuk menuju kesuksesan dan menghindari kegagalan hidup dengan kata lain motivasi adalah sebuah proses untuk tercapainyasuatu tujuan. Seseorang yang mempunyai motivasi berarti ia telah mempunyai kekuatan untuk memperoleh kesuksesan dalam kehidupan. Motivasi dapat berupa motivasi intrinsik dan ekstrinsik. Motivasi yang bersifatintrinsik adalah manakala sifat pekerjaan itu sendiri yang membuat seseorang termotivasi,orang tersebut mendapat kepuasaan dengan melakukan pekerjaan tersebut bukan karena rangsangan lain seperti status ataupun uang atau bisa juga dikatakan seorang melakukan hobbynya. Sedangakan motivasi ekstrinsik adalah manakala elemen elemen diluar pekerjaan yang melekat dipekerjaan tersebut menjadi faktor utama yang membuat seorang termotivasi seperti status ataupun kompensasi.

Selain budaya organisasi dan komunikasi yang perlu diperhatikan dalam peningkatan produktivitas karyawan adalah lingkungan kerja dalam perusahaan. Lingkungan kerja yang menyenangkan bagi karyawan melalui pengikatan hubungan yang harmonis dengan atasan, rekan kerja, maupun bawahan, serta didukung dengan sarana dan prasarana yang memadai yang ada di tempat bekerja akan membawa dampak yang positif bagi karyawan.Dengan adanya kepuasan kerja karyawan, akan menumbuhkan komitmen dalam diri mereka pada perusahaan, sehingga karyawan akan merasa ikut memiliki organisasi dan mencurahkan segala daya dan kemampuan untuk keberhasilan organisasi. Jika hal tersebut bisa tercapai, maka karyawan akan lebih berinovasi dan mengembangkan kreatifitasnya dalam bekerja dan memberikan pelayanan yang terbaik terhadap nasabah, yang nantinya akan menambah jumlah nasabah untuk menabung di PT. Bank Bukopin (Persero) Tbk. Cabang Denpasar dan sendirinya akan memupuk laba dari perusahaan.

Fenomena yang terjadi mengakibatkan menurunnya kinerja PT.Bank Bukopin (persero) adalah akibat dari tingkat turn over yang cukup tinggi. Lebih lanjut bahwa faktor utama yang menyebabkan tingkat turn over karyawan bagian marketing cukup tinggi adalah ketidakmampuan karyawan tersebut dalam mencapai target yang ditetapkan perusahaan.Ketidakmampuan karyawan dalam mencapai target yang ditetapkan perusahaan dapat disebabkan oleh stres kerja. Jika melihat kasus PT. Bank Bukopin (persero) diatas,dapat disimpulkan bahwa faktor utama yang menyebabkan turnover yang cukup tinggi ini adalah stres kerja.

Hasibuan (2007)mengemukakan bahwa stress kerja adalah suatu kondisi ketegangan yang mempengaruhi emosi,proses berpikir dan kondisi seseorang.Stress kerja adalah suatu kondisi ketegangan yang menciptakan adanya ketidakseimbangan fisik dan psikis yang mempengaruhi emosi,proses berpikir dan kondisi seorang pegawai.Sehubungan dengan hal tersebut PT. Bank Bukopin (Persero) Tbk. Cabang Denpasar sebagai organisasi yang bergerak di bidang perbankan yang berlokasi di Jalan Dewi Sartika No.2Denpasar, 
senantiasa berupaya agarterciptanya kepuasan kerja pada karyawan. Hal ini dimaksudkan agar karyawan dapat bekerja dengan baik dalam memberikan pelayanan kepada nasabah, kemauan untuk bekerja sama, memiliki disiplin kerja yang tinggi, minat yang tinggi terhadap perusahaan.jumlah karyawan PT. Bank Bukopin cabang Denpasar sebanyak 90 orang karyawan yang memiliki latar belakang yang berbeda-beda baik pendidikannya, pengalaman kerja, jabatan dan masa kerja. Sejumlah alasan yang melatar belakangi kepuasan kerja karyawan, seperti gaji yang lebih rendah dan penyesuaian-penyesuaian lebih baik terhadap situasi kerjakarena lebih berpengalaman.Dalam hal ini, kepuasan kerja menjadi hal yang sangat diperhatikan oleh perusahaan, karena dengan terjaminnya kepuasan kerja diharapkan dapat meningkatkan kinerja karyawan.

Peningkatan kepuasan kerja pada suatu organisasi tidak bisa dilepaskan dari peranan pimpinan dalam organisasi tersebut, kepemimpinan merupakan kunci utama dalam manajemen dalam memainkan peran penting dan strategi dalam kelangsungan hidup suatu perusahaan.Pemimpin merupakan pencetus tujuan, merencanakan, mengorganisasikan, menggerakkan dan mengendalikan seluruh sumber daya manusia yang dimiliki sehingga tujuan perusahaan dapat tercapai secara efektif dan efisien. Kepemimpinan manajerial dapat didefinisikan sebagai sesuatu proses pengarahan dan pemberian pengaruh pada kegiatankegiatan dari sekelompok anggota yang saling berhubungan tugasnya As'ad (2005). Oleh sebab itu pemimpin suatu organisasi perusahaan dituntut untuk selalu mampu menciptakan kondisi yang mampu memuaskan karyawan dalam bekerja sehingga memperoleh karyawan yang tidak hanya mampu bekerja akan tetapi juga bersedia kearah pencapaian tujuan perusahaan.Sejalan dengan itu diharapkan seorang pemimpin memotivasi dan menciptakan kondisi sosial yang menguntungkan setiap karyawan sehingga tercapainya kepuasan kerja karyawan yang berimplikasi pada meningkatnyaproduktivitas kerja karyawan. Berdasarkan hasil pengamatan yang dilakukanpadaPT. Bank Bukopin (Persero) Tbk. Cabang Denpasar, adanyaperlakuan yang berbeda terhadap beberapa karyawan dari atasanya menyebabkan sulitnya membangun kredibilitas dan kepercayaan karyawanterhadap atasannya, serta sikap pemimpin yang kurang jelas dalam menyampaikan perintah mengakibatkan pegawai sering salah pengertian.

Kepuasan kerja merupakan hal yang bersifat individu sehingga akan terjadi dinamika atau perubahan-perubahan setiap waktu yang harus diantisipasi agar tidak berkembang kearah hal-hal yang bersifat negatif yang merugikan organisasi. Tiap inividu mempunyai tingkat kepuasan yang berbedabeda dengan nilai-nilai yang berlaku pada dirinya, semakin banyak aspek dalam pekerjaan yang sesuai dengan keinginan maka semakin tinggi tingkat kepuasan yang dirasakan dan begitu pula sebaliknya.Kepuasan dan semangat kerja adalah istilah serupa yang menunjukkan sampai seberapa jauh organisasi membutuhkan para karyawan. Ukuran kepuasan meliputi sikap karyawan, pengantian karyawan (turn over), kemangkiran ketelambatan, dan keluhan. Luthans (2006) menyatakan yang memberikan divisi tentang kepuasan kerja sebagai suatu keadaan emosi yang senang atau emosi positif yang berasal dari penilaian pekerjaan atau pengalaman seseorang.Kepuasan kerja sebagai sikap umum seorang individu terhadap pekerjaannya.Seseorang dengan tingkat 
kepuasan kerja tinggi menjukkan sikap positif terhadap pekerjaanya dan seseorang yang tidak puas dengan pekerjaannya menunjukkan sikap negatif terhadap pekerjaanya itu.Untuk meningkatkan kepuasan kerja karyawan, organisasi harus merespon kebutuhan karyawan.Kepuasan kerja merupakan hasil dari berbagai macam sikap yang dimiliki oleh seorang pekerja. Sikap ini dikaitkan dengan pekerja dan faktor-faktor khusus seperti upah, insentif dan supervisi kestabilan pekerjaan, ketentraman kerja, kesempatan untuk maju, penilaian yang adil, hubungan sosial, di dalam pekerjaan dan perlakuan, faktor individual seperti umur, kesehatan, watak dan harapan seharusnya dipertimbangkan. Faktor-faktor utama yang mempengaruhi kepuasan kerja adalah pekerjaan itu sendiri, upah, promosi, pengawasan, rekan kerja, dan kondisi kerja. Robbins (2009) menyatakan efek kepuasan kerja karyawan adalahkepuasan serta produktifitas, kepuasan serta kemangkiran, dan kepuasan serta tingkat keluarnya karyawan.

Robbins (2009) menyatakan bahwa ketidakpuasan karyawan dapat dijelaskan adalah keluar(exit), aspirasi (voice), kesetiaan(loyalty), dan pengabaian(neglect). Yuwono (2005) menyatakan bahwa indikator kepuasan kerja dapat dilihat dari sembilan aspek yaitu kepuasan kerja terhadap kesempatan promosi untuk kenaikan jabatan, kepuasan terhadap gaji yang diterima dan kesempatan memperoleh kenaikan gaji dan kepuasan terhadap segala kebijakan, prosedur dan aturan perusahaan.Kepuasan kerja sebagai sikap umum seorang individu terhadap pekerjaannya.Seseorang dengan tingkat kepuasan kerja tinggi menjukkan sikap positif terhadap pekerjaanya dan seseorang yang tidak puas dengan pekerjaannya menunjukkan sikap negatif terhadap pekerjaanya itu.Pekerjaan seseorang tidak hanya sekedar melakukan pekerjaan tetapi pekerjaan menuntut interaksi dengan rekan bekerja dan atasan, mengikuti aturan dan kebijakan organisasi, memenuhi standar kinerja, hidup pada kondisi kerja yang sering kurang dan ideal dan hal serupa lainnya. Hal ini menunjukkan bahwa kepuasan kerja seseorang dipengaruhi oleh banyak faktor tidak hanya gaji tetapi terkait dengan faktor lain seperti pekerjaan itu sendiri, karakteristik individu lingkungan kerja, rekan kerja, dan hubungan dengan atasan.

Untuk meningkatkan kepuasan kerja karyawan, organisasi harus merespon kebutuhan karyawan.Kepuasan kerja merupakan hasil dari berbagai macam sikap yang dimiliki oleh seorang pekerja. Sikap ini dikaitkan dengan pekerja dan faktor-faktor khusus seperti upah, insentif dan supervisi kestabilan pekerjaan, ketentraman kerja, kesempatan untuk maju, penilaian yang adil, hubungan sosial, di dalam pekerjaan dan perlakuan

Sri (2005) menyatakan bahwa berpendapat dalam kaitannnya dengan kesuksesanpemimpin dalam sebuah organisasi, nampaknya seorang pemimpin harusmempunyai sifat-sifat sebagai berikut : 1) Watak dan kepribadian terpuji, 2)Keinginan melayani karyawan, 3)Memahami kondisi lingkungan, 4) Intelegensi yang tinggi, 5) Berorientasi ke depan dan 6) Sikap terbuka dan lugas.

Banyak pendekatan yang digunakan untuk membedakan kepemimpinan. Salah satunya yang umum dikenal adalah yang menyatakan bahwa para pemimpin pada dasarnya dapat dikategorikan menjadi lima. Djatmiko (2002) yang dikutip oleh Ardana (2009)menyatakan, yaitu sebagai berikut : 1) Tipe 
otoraktik, 2) Tipe patemalistik, 3) Tipe karismatis, 4) Tipe laissesfaire (Free Reign), dan Tipe Demokratis (Partisipasif). Thoha (2001) menyatakan bahwa ,beberapa indikator-indikator mengenai gaya kepemimpinan dapat dijelaskan sebagai berikut : 1) Perilakuinstruksi, 2) Perilaku kosultatif, 3) Perilakupartisipasif dan 4) Perilaku delegatif.

Kartono (2003), menyatakan bahwa metode kepemimpinan adalah suatu cara bekerja dan bertingkah seorang pemimpin dalam membimbing bawahan atau karyawannya. Metode-metode kepemimpinan antara lain sebagai berikut :1) Memberi perintah, 2)Memberi celaan dan pujian, 3)Memupuk tingkah laku pemimpin yang benar, 4)Memperketat rasa kesatuan kelompok, 5) Peka terhadap saran-saran, 6) Menciptakan disiplin diri dan disiplin kelompok dan 7)Meredam kabar angin dan isu-isu yang tidak benar.

Selain kepemimpinan salah satu faktor yang digunakan untuk meningkatkan kepuasan kerja karyawan PT. Bank Bukopin (Persero)Tbk. Cabang Denpasar adalah dengan pemberian kompensasi. Kompensasi merupakan sebuah komponen penting dalam hubungan dengan kepuasan kerja karyawan karena dapat memotivasi karyawan agar bekerja untuk mencapai produktivitas yang semakin tinggi. Kompensasi yang diberikan adalah berupa gaji, tunjangan makan, tunjangan hari raya, dan insentif. Perusahaan berusaha mengelola pemberian kompensasi dengan baik untuk dapat meningkatkan kepuasan kerja karyawan. Jika kompensasi tidak dikelola dengan baik, dapat menyebabkan ketidakpuasan pada karyawan. Akibat dari ketidakpuasan tersebut dapat mengurangi kinerja,meningkatkan keluhan-keluhan, penyebab mogok kerja, dan meningkatkan derajat ketidakhadiran dan perputaran karyawan Simamora (2004), menyatakan kompensasi merupakan apa yang diterima oleh para karyawan sebagai ganti kontribusi mereka kepada organisasi. Pengaturan kompensasi merupakan faktor penting untuk dapat menarik, memelihara maupun mempertahankan tenaga kerja bagi kepentingan organisasi. Kompensasi adalah pengaturan keseluruhan pemberian balas jasa bagi employers yang langsung berupa uang (finansial) maupun tidak langsung berupa uang (non finasial).

Mudiartha (2001) menyatakan bahwa fungsi dan tujuan pemberian kompensasi adalah sebagai berikut : Ikatan Kerja Sama, Kepuasan Kerja, Pengadaan Efektif, Motivasi, Stabilitas Karyawan, Disiplin, Pengaruh Serikat Buruh, dan Pengaruh Pemerintah. Simamora (2004) kompensasi dibedakan menjadi 2 yaitu: Kompensasi Finansial dan Kompensasi Non Finansial. Adapun yang dimaksud dengan kompensasi non finansial adalah kepuasan yang diperoleh seseorang dari pekerjaannya itu sendiri atau darilingkungan psikologis atau fisik dimana orang tersebut bekerja.

Menurut Mudiartha (2001) faktor-faktor yang mempengaruhi kompensasi adalah sebagai berikut: Penawaran dan permintaan tenaga kerja, Kemampuan dan kesediaan perusahaan, Serikat buruh dan organisasi karyawan, Produktivitas kerja karyawan, Pemerintah dengan UU dan Keppres, Biaya hidup dan cost of living, Posisi jabatan karyawan, Pendidikan dan pengalaman kerja, Kondisi perekonomian nasional dan Jenis dan sifat pekerjaan.

Menurut Nitisemito (2000) syarat-syarat pemberian kompensasi seperti berikut ini : Kompensasi harus bersifat mengikat, Kompensasi harus layak dan 
memenuhi kebutuhan minimal, Kompensasi harus dapat menimbulkan semangat dan kegairahan kerja, Kompensasi harus adil, Kompensasi tidak boleh bersifat statis dan Kompensasi dalam bentuk lain.

Menurut Simamora (2004),Kompensasi dapat dibagi menjadi dua klasifikasi, yaitu sebagai berikut :

Kompensasi finansial : Kompensasi financial secara langsung dan Kompensasi finansial secara tidak langsung. Kompensasi nonfinansial adalah kompensasi yang dapat berwujud kepuasan yang diperoleh seseorang dari pekerjaan itu sendiri, atau lingkungan psikologis dan fisik dimana orang tersebut bekerja. Meliputi: Kompensasi yang didapatkan dari pekerjaan yang berupa tugas-tugas yang menarik, penuh tantangan, tanggung jawab, pengakuan dan rasa pencapaian,Lingkungan pekerjaan yang berupa kebijakan-kebijakan yang sehat, struktur visi yang kompeten, suasana kerja yang menyenangkan dan lingkungan kerja yang nyaman.

Dari uraian diatas maka kompensasi dibedakan menjadi dua yaitu kompensasi finansial dan non finansial. Pembayaran kompensasi ada yang dikaitkan langsung seperti upah atau gaji, bonus atau komisi sehingga sering disebut kompensasi langsung.Dan ada yang tidak dikaitkan langsung dengan kinerja sebagai upaya meningkatkan ketenangan dan kepuasan kerja pegawai seperti pemberian fasilitas dan asuransi.Menurut Harahap (2009), Investor dalam melakukan investasi di pasar modal secara umum lebih memilih perusahaan yang profitable, sebab dengan memilih perusahaan yang profitable investor akan mendapatkan keuntungan

Profit merupakan salah satu indikator yang digunakan untuk mengukur kemampuan perusahaan dalam menghasilkan laba dengan aktiva yang dimilikinya.Jadi semakin besar perusahaan, maka semakin tinggi kepuasan kerja di perusahaan tersebut dalam pemberian upah gaji maupun kompensasi yang diterima setiap karyawan Bukopin Denpasar. Besar laba maka kepuasan kerja akan semakin meningkat. Meningkatnya kepuasan kerja akan meningkatkan profit, dikarenakan karyawan akan semakin giat dalam bekerja guna mencapai target perusahaan. Hal ini akan berdampak pada pemberian kompensasi terhadap karyawan PT. Bank Bukopin (Persero) Tbk. Cabang Denpasar.Kompensasi merupakan salah satu upaya yang dilakukan oleh manajemen untuk meningkatkan prestasi kerja, motivasi, dan kepuasan. Sedangkan profit merupakan keuntungan yang diperoleh perusahaan sebagai pemasukan perusahaan dalam pemberian kompensasi setiap karyawannya.

Tabel 1. Laba PT. Bank Bukopin (Persero) Tbk. Cabang DenpasarPeriode Januari-Desember 2016.

\begin{tabular}{lcc}
\hline \multicolumn{1}{c}{ Bulan } & & Laba per Bulan \\
\hline Januari & $\mathrm{Rp}$ & $178,893,500,926,500$ \\
Pebruari & $\mathrm{Rp}$ & $150,620,348,007,000$ \\
Maret & $\mathrm{Rp}$ & $126,659,983,300,050$ \\
April & $\mathrm{Rp}$ & $138,956,746,548,000$ \\
Mei & $\mathrm{Rp}$ & $143,689,638,750,000$ \\
\hline
\end{tabular}

Bersambung... 
Lanjutan Tabel 1.

\begin{tabular}{llr}
\hline Juni & $\mathrm{Rp}$ & $172,245,634,540,003$ \\
Juli & $\mathrm{Rp}$ & $176,576,667,800,050$ \\
Agustus & $\mathrm{Rp}$ & $165,673,890,390,008$ \\
September & $\mathrm{Rp}$ & $176,373,675,050,000$ \\
Oktober & $\mathrm{Rp}$ & $170,940,456,387,449$ \\
Nopember & $\mathrm{Rp}$ & $147,497,074,500,900$ \\
Desember & $\mathrm{Rp}$ & $185,872,383,800,040$ \\
Laba Tahunan & $\mathrm{Rp}$ & $1,934,000,000,000,000$ \\
\hline
\end{tabular}

Sumber: PT. Bank Bukopin (Persero) Tbk. Cabang Denpasar, 2016

\section{METODE PENELITIAN}

Penelitian ini dilakukan di PT. Bank Bukopin (Persero) Tbk. Cabang Denpasar yang berlokasi di Jalan Dewi Sartika No.2 Denpasar. Penelitian ini dilakukan karena ditemukannya permasalahan yang terkait dengan kepemimpinan, kompensasi dan kepuasan kerja karyawan PT. Bank Bukopin (Persero) Tbk.

Dalam penelitian ini yang menjadi obyek penelitian yang akan diteliti ini adalah mengenai kepemimpinan kompensasi dan laba yang mempengaruhi kepuasan kerja karyawan pada PT.Bank Bukopin (Persero) Tbk.Cabang Denpasar. Jumlah sampel yang diambil sebanyak 89 orang karyawan dengan metode pengumpulan data dilakukan dengan menggunakan kuesioner.

Variabel dalam penelitian ini diidentifikasi menjadi variabel terikat dan variabel bebas. Adapun sebagai variabel terikat dan variabel bebas yaitu:Variabel terikat merupakan variabel yang dipengaruhi oleh variabel lain. Dalam penelitian ini adalah yang menjadi variabel terikat adalah kepuasan kerja karyawan yang dinotasikan sebagai variabel Y.Variabel bebas merupakan variabel yang mempengaruhi variabel terikat.

Dalam penelitian ini, variabel bebas dinotasikan sebagai variabel $X$ yang terdiri dari: 1) Kepemimpinan (X1), 2) Kompensasi (X2) dan 3) Laba (X3). Adapun sumber data dalam penelitian ini adalah sebagai berikut:

Data primer adalah Data yang dikumpulkan dan diamati dari sumbernya sarta memerlukan pengolahan lebih lanjut terhadap data tersebut. Data primer dalam penelitian ini yaitu pertanyaan responden dalam pengisian kuesionerData sekunder adalah Data yang diperoleh melalui pihak lain dan buku-buku yang ada hubungannya dengan penelitian ini. Data ini meliputi jumlah karyawan, sejarah singkat perusahaan, serta struktur organisasi.

Teknik pengambilan sampel dalam penelitian ini adalah teknik nonprobability sampling yaitu setiap elemen dalam populasi tidak memiliki peluang yang sama untuk dipilih menjadi sampel dimana pemilihan sampel dilakukan dengan tidak acak dan bersifat subjektif. Teknik non probability sampling yang dipergunakan dalam penelitian ini adalah purposive sampling yaitu anggota memilih anggota sampel yang disesuaikan dengan kriteria tertentu.Bahwa yang termasuk penentuan sampel adalah karyawan tetap PT. Bank Bukopin (Persero) Tbk. Cabang Denpasar yang berjumlah 89 orang dengan kriteria bahwa direktur tidak termasuk kedalam responden karena direktur 
PT.Bukopin (Persero) Tbk. Cabang Denpasar adalah kepala kantor cabang tersebut.

Adapun metode pengumpulan data dilakukan dengan cara: Observasi adalah pengumpulan data dengan melakukan pengamatan langsung ke PT. Bank Bukopin (Persero) Tbk. Cabang Denpasar untuk mengamati perilaku dan proses kerja karyawan. Wawancara adalah metode pengumpulan data dengan cara melakukan tanya jawab langsung baik dengan manajer dan karyawan bagian operasional pada PT. Bank Bukopin (Persero) Tbk. Cabang Denpasar yang akan diteliti.

Kuesioner adalah pengumpulan data dengan menggunakan daftar pertanyaan yang disebarkan kepada responden yaitu karyawan PT. Bukopin (Persero) Tbk. Cabang Denpasar untuk dimintai keterangan terhadap sesuatu yang dialami dan berhubungan dengan masalah yang dibahas dalam penelitian ini.

\section{HASIL DAN PEMBAHASAN}

Analisis regresi linear berganda ini digunakan untuk tujuan penelitian yang pertama. Yaitu untuk menganalisis pengaruh kepemimpinan dan kompensasi sebagai variabel independen (Xi....Xn) terhadap kepuasan kerja karyawan pada PT.Bank Bukopin (Persero) Tbk. Cabang Denpasar yang berfungsi sebagai variabel dependen $(Y)$. Sebelum dilakukan analisis regresi linear berganda data yang diperoleh terlebih dahulu diubah dari skala ordinal menjadi skala interval dengan menggunakan Method of SuccessiveInterval (MSI).

Persamaan regresi linear berganda :

$$
Y=\alpha+\beta 1 X 1+\beta 2 X 2+\beta 2 X 3
$$

Keterangan:

$\mathrm{Y}=$ Variabel kepuasan kerja karyawan

$\mathrm{XI}=$ Kepemimpinan,

$\mathrm{X} 2=$ Kompensasi

$\mathrm{X} 3=\mathrm{Laba}$

$a=$ Nilai $Y$ bila $X=0$

$\beta 1=$ Koefisien regresi kepemimpinan, $\beta 1=$ koefisien regresi kompensasi

e =error atau sisa (residual)

\section{Tabel 2. Hasil Uji Regresi Linear Berganda}

\begin{tabular}{lccccc}
\hline Model & \multicolumn{2}{l}{$\begin{array}{l}\text { Unstandardized } \\
\text { Coefficients }\end{array}$} & $\begin{array}{c}\text { Standardized } \\
\text { Coefficients }\end{array}$ & T & \multirow{2}{*}{$\begin{array}{l}\text { Si } \\
\text { g. }\end{array}$} \\
\cline { 2 - 4 } & $B$ & Std. Error & Beta & & \\
\hline (Constant) & 19,137 & 7,984 & & 2,397 & 0,043 \\
Kepemimpinan & 1,183 & 0,415 & 0,646 & 2,850 & 0,021 \\
Kompensasi & 55,557 & 23,001 & 22,249 & 2,415 & 0,042 \\
Laba Bersih & 1240,217 & 521,595 & 21,979 & 2,378 & 0,045 \\
\hline
\end{tabular}

Sumber: Data Penelitian, 2016

Berdasarkan tabel 2 maka dapat diketahui persamaan regresi yang dihasilkan.

$$
\mathrm{Y}-19,137+1,183 \mathrm{X} 1+55,557 \mathrm{X} 2+1240,217 \mathrm{X} 3+\mathrm{e}
$$

Dimana :

$\mathrm{Y} \quad=$ Variabel Kepuasan Kerja Karyawan 


$$
\begin{array}{ll}
\mathrm{X} 1 & =\text { Kepemimpinan } \\
\mathrm{X} 2 & =\text { Kompensasi } \\
\mathrm{X} 3 & =\text { Laba Bersih } \\
\mathrm{e} & =\text { Adalah error atau sisa (residual) }
\end{array}
$$

Uji Validitas dalam penelitian dijelaskan sebagai suatu ketepatan alat ukur penelitian tentang inti atau arti sebenarnya yang diukur.Tinggi rendahnyavaliditas menunjukkan sejauh mana data yang terkumpul tidak menyimpang dari gambaran tentang variabel yang dimaksud. Hasil uji validitas ditunjukkan pada Tabel 3 dibawah ini.

\section{Tabel 3. Hasil Uji Validitas}

\begin{tabular}{llll}
\hline No & Variabel & $\begin{array}{l}\text { Koefiesien Korelasi } \\
\text { (r hitung) }\end{array}$ & Simpulan \\
\hline 1 & Kepuasan Kerja & 0,908 & \\
& Y.1 & 0,795 & Valid \\
& Y.2 & 0,855 & Valid \\
& Y.3 & 0,541 & Valid \\
& Y.4 & 0,780 & Valid \\
& Y.5 & 0,629 & Valid \\
& Y.6 & 0,661 & Valid \\
& Y.7 & 0,814 & Valid \\
& Y.8 & 0,923 & Valid \\
& Y.9 & 0,554 & Valid \\
& Y.10 & & Valid \\
& Kepemimpinan & & \\
& X1.1 & 0,589 & Valid \\
& X1.2 & 0,685 & Valid \\
& X1.3 & 0,654 & Valid \\
& X1.4 & 0,666 & Valid \\
& X1.5 & 0,494 & Valid \\
& X1.6 & 0,756 & Valid \\
& X1.7 & 0,822 & Valid \\
X1.8 & 0,598 & Valid \\
Kompensasi & & \\
& X2.1 & 0,796 & Valid \\
& X2.2 & 0,758 & Valid \\
& X2.3 & 0,911 & Valid \\
& X2.4 & 0,580 & Valid \\
& X2.5 & 0,854 & Valid \\
\hline
\end{tabular}

Sumber: Data Penelitian, 2016

Berdasarkan Tabel 3 diketahui bahwa korelasi ( $\mathrm{r}$ hitung) antara skor item instrumen dengan skor total seluruh item pertanyaan lebih dari 0,3. Jadi seluruh instrumen dapat dinyatakan layak digunakan sebagai alat ukur.

Uji Reliabilitas adalah derajat kecepatan, ketelitian atau keakuratan yang ditunjukkan oleh instrumen pengukuran dimana pengujiannya dapat dilakukan secara internal, yaitu pengujian dengan menganalisa konsisten butirbutir yang ada.Hasil uji reliabilitas ditunjukkan pada Tabel 4 dibawah ini. 
Tabel 4. Hasil Uji Reliabilitas

\begin{tabular}{llll}
\hline No. & Variabel & $\begin{array}{l}\text { Cronbach's } \\
\text { Alpha }\end{array}$ & Simpulan \\
\hline 1 & Kepuasan Kerja & 0,913 & Reliabel \\
2 & Kepemimpinan & 0,808 & Reliabel \\
3 & Kompensasi & 0,843 & Reliabel \\
\hline
\end{tabular}

Sumber: Data Penelitian, 2016

Tabel 4 menunjukkan bahwa nilai Cronbach's Alpha untuk setiap variabel lebih besar dari 0,6. Jadi dapat dinyatakan bahwa seluruh variabel telah telah memenuhi syarat reliabilitas atau kehandalan.

Uji Multikolinearitas dimaksudkan untuk membuktikan atau menguji ada atau tidaknya hubungan yang linear (multikolinearitas) antara variabel bebas (independen) satu dengan variabel bebas yang lain. Hasil uji multikolinearitas ditunjukkan pada Tabel 5.

Tabel 5. Hasil Uji Multikolinearitas

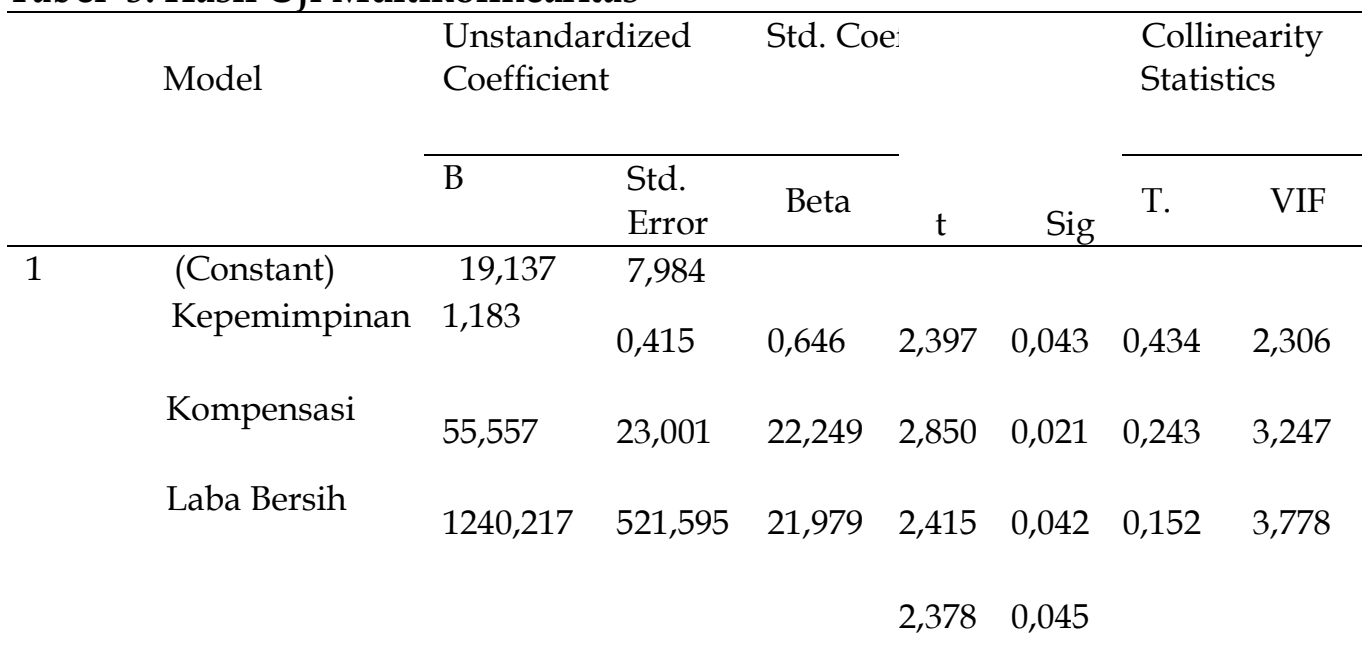

Sumber: Data Penelitian, 2016 dihasilkan.

Berdasarkan tabel 5 maka dapat diketahui persamaan regresi yang

Hasil uji tersebut menunjukkan bahwa thitung $(2,397)$ lebih besar dari $t$ tabel $(1,988)$ dan nilai signifikan sebesar 0,000 yang lebih kecil dari alpha $(\mathrm{a}=0,05)$. Sehingga dapat disimpulkan $\mathrm{H}_{0}$ ditolak yang berarti kepemimpinan secara parsial berpengaruh positif dan signifikan terhadap kepuasan kerja karyawan PT.Bank Bukopin (Persero) Tbk.Cabang Denpasar.

Hasil tersebut menunjukkan bahwa t hitung $(2,397)$ lebih besar dari $t$ tabel $(1,988)$ dan nilai signifikan lebih kecil dari alpha $(a=0,05)$. Sehingga dapat disimpulkan $\mathrm{H}_{0}$ ditolak yang berarti kompensasi secara parsial berpengaruh positif dan signifikan terhadap kepuasan kerja karyawan PT.Bank Bukopin (Persero) Tbk.Cabang Denpasar.

Laba merupakan pendapatan perusahaan dikurangi biaya eksplisit atau biaya akutansi perusahaan. Hasil penelitian ini menunjukkan bahwa laba berpengaruh terhadap kepuasan kerja karyawan.

$$
\text { Y }-19,137+1,183 X 1+55,557 X 2+1240,217 X 3+e
$$


Dimana :

$\mathrm{Y} \quad=$ Variabel Kepuasan Kerja Karyawan

$\mathrm{X} 1=$ Kepemimpin an , X2 = Kompensasi , X3 = Laba Bersih

$\mathrm{e}=$ Adalah error atau sisa (residual)

Tabel 6. Hasil Pengujian Autokorelasi

\begin{tabular}{llllll}
\hline Model & $\mathrm{R}$ & $\begin{array}{l}\mathrm{R} \\
\text { Square }\end{array}$ & $\begin{array}{l}\text { Adjusted } \mathrm{R} \\
\text { Square }\end{array}$ & $\begin{array}{l}\text { Std. Error of } \\
\text { the Estimate }\end{array}$ & $\begin{array}{l}\text { Durbin- } \\
\text { Watson }\end{array}$ \\
\hline 1 & $\begin{array}{l}0,907 \\
(\mathrm{a})\end{array}$ & 0,822 & 0,755 & 3,83494 & 1,884 \\
\hline
\end{tabular}

Sumber: Data Penelitian, 2016

Tabel 6 diketahui nilai Durbin-Watson pada model regresi linear berganda ini adalah sebesar 1,884 ini terletak di antara $(\mathrm{du}-1,70)$ dan $\left(\mathrm{d}^{\wedge}=\right.$ 1,61), sehingga dapat disimpulkan bahwa model regresi ini tidak mengalami autokorelasi. Besarnya nilai Adjusted $\mathrm{R}^{2}$ adalah 0,755 artinya75,5 persen kepemimpinan, kompensasi dan laba berpengaruh terhadap kepuasan kerja karyawan PT. Bank Bukopin (Persero) Tbk. Cabang Denpasar.

Hasil uji kelayakan model pada tabel 2 menunjukkan bahwa signifikan sebesar lebih kecil dari alpha $(a=0,05)$ Nilai F Hitung sebesar 80,203 dimana lebih kecil dari alpha $(\mathrm{a}=0,05)$, yang berarti model layak,hal tersebut menunjukkan bahwa kepemimpinan, kompensasi dan laba berpengaruh signifikansi terhadap kepuasan kerja karyawan PT. Bank Bukopin (Persero) Tbk. Cabang Denpasar.

Hasil uji Hipotesis tersaji pada tabel 2 menunjukkan nilai signifikansi sebesar 0,000 yang lebih kecil dari alpha $(a=0,05)$. Adapun nilai variabel kepemimpinan sebesar 0,021 lebih kecil dari alpha $(a=0,05)$. Jadi dapat disimpulkan bahwa kepemimpinan berpengaruh positif dan signifikan terhadap kepuasan kerja karyawan PT. Bank Bukopin (Persero) Tbk. Cabang Denpasar. Hal ini menunjukkan kepemimpinan berperan penting dalam mewujudkan kepuasan kerja karyawan. Selain itu kepemimpinan merupakan suatu unsur penting dan sangat mempengaruhi kinerja, motivasi dan kepuasan kerja karyawan.Hasil uji Hipotesis pada tabel 2 menunjukkan nilai variabel kompensasi sebesar 0,042 yaitu nilai signifikansi lebih kecil dari alpha $(\mathrm{a}=0,05)$.

Jadi dapat disimpulkan bahwa kompensasi berpengaruh positif dan signifikan terhadap kepuasan kerja karyawan PT. Bank Bukopin (Persero) Tbk. Cabang Denpasar.Kompensasi berperan meningkatkan kepuasan kerja karyawan, semakin tinggi kompensasi maka semakin besar kepuasan kerja karyawan. Kompensasi sangat menunjang kinerja karyawan dalam meningkatkan prestasi kerja,untuk itu pemberian kompensasi sangat berperan di dalam menciptakan kepuasan kerja dan karyawan akan lebih terpenuhi dan termotivasi untuk mencapai sasaran - sasaran perusahaan.

Laba merupakan pendapatan perusahaan dikurangi biaya eksplisit atau biaya akuntansi perusahaan. Jumlah laba yang dihasilkan dapat dipakai sebagai salah satu alat ukur efektivitas perusahaan karena laba merupakan keuntungan yang diterima perusahaan . Hasil penelitian ini menunjukkan bahwa laba berpengaruh terhadap kepuasan kerja karyawan, dengan nilai signifikansi sebesar 2,378 lebih kecil dari alpha $(a=0,05)$. Dari pencapaian 
laba akan meningkatkan kepuasan kerja karyawan, selain itu laba perusahaan berperan penting dalam pengelolaan keuangan baik itu dalam pemberian kompensasi karyawan guna menciptakan kepuasan kerja tiap karyawan. Laba juga merupakan prestasi seluruh karyawan dalam suatu perusahaan.

\section{SIMPULAN}

Berdasarkan hasil analisis dan uraian pada bab-bab sebelumnya, maka diperoleh simpulan bahwa 1) kepemimpinan berpengaruh terhadap kepuasan kerja karyawan PT. Bank Bukopin (Persero) Tbk Cabang Denpasar, 2)kompensasi berpengaruh terhadap kepuasan kerja karyawan PT. Bank Bukopin (Persero) Tbk Cabang Denpasar, 3) Laba berpengaruh terhadap kepuasan kerja karyawan karyawan PT. Bank Bukopin (Persero) Tbk Cabang Denpasar.

\section{REFERENSI}

Acheampong, Philip, Stacey I, Deshield and Hsin-Ling Tsai. 2010. The Impact of job Mobility, Hourly Compensation, and Work Hour on Job Satisfaction. Institude For Research In Training \& Development.

Al-Hussami, RN, Mahmoud. 2008. A Study of Nurses' Job Satisfaction. The Relationship to Organizational Commitment, Perceived Organizational Support, Transactional Leadership, Transformational Leadership, and Level of Education. European Journal of Scientific Research, 22(22): h: 286-295.

Ardana, Komang, Ni Wayan Mujiati, Anak Agung Ayu Sriathi. 2009. Perilaku Keorganisasian. Edisi 2. Yogyakarta: Graha Ilmu.

Brahmasari, Ida Ayu dan Agus Suprayetno. 2008. "Pengaruh Motivasi Kerja, Kepemimpinan dan Budaya Organisasi Terhadap Kepuasan Kerja Karyawan serta Dampaknya pada Kinerja Perusahaan (Studi kasus pada PT. Pei Hai International Wiratama Indonesia)". Jurnal Manajemen.

Dwi Wira Ardana, I Made, 2008. Pengaruh Kepemimpinan Dan Karakteristik Pekerjaan Terhadap Kepuasan Kerja Karyawan di Lembaga Pendidikan Pariwisata (LPP) Dhayana Pura.Skripsi Sarjana Mahasiswa Manajemen Fakultas Ekonomi Universitas Udayana, Denpasar.

Harahap, Sofyan Syafri. 2009 .Teori Akuntansi Laporan Keuangan .Jakarta : Bumi Aksara

Ho, Wen-Hsien. 2009. Effects of job rotation and role stress among nurses on job satisfaction and organizational commitment. Published online. 9(8): h:70-72.

Luthans, Fred, 2006, Perilaku Organisasi. Edisi Kesepuluh (Penerjemah : Vivin Andhika Yuwono; Shekar Purwanti; Th. Arie Prabawati; dan winong Rosari). Yogyakarta: Andi.

Mudiartha Utama, Wayan Mujiati, dan Komang Ardana. 2001. Manajemen Sumber Daya Manusia. Denpasar: UPT Penerbit Universitas Udayana.

Papalexandris, Nancy and Eleanna Galanaki. 2009. Leadership's Impact on Employee Eengagement : Differences Among Entrepreneurs and Professional CEOs. Leadership Development Journal. Vol.30, No.4, pp : 365-385, September 101.

Robbins Stephen P dan Timothy A. Judge. 2009. Perilaku Organisasi. Edisi 12.Jakarta: Salemba Empat.

Stephen, Betts C and Santoro, Michael D. 2007. Integrating Leadership Theories 
and Team Research : A Conceptual Framework Based on Level of Analysis and Type of Control. Journal of Organizational Culture, Communication and Conflict. Vol 11, No. 1, pp : 1-17, September 101.

Yang, Li-Ren, et. All.2010. Relationship Among Project Manager's Leadership Style, Team Interaction and Project Performance in The Taiwanese Server Industry. Research Paper. Qual Quant. Vol. 46,pp : 207-219, September 101.

Yulinda, Sri Wulan Hariyanti. 2009. Faktor-faktor yang Mempengaruhi Kepuasan Kerja Pegawai pada Dinas Luar Asuransi Jiwa Bersama Bumiputera 1912 Cabang Setiabudi Medan. Jurnal Manajemen Bisnis. 2(1): h:25-32.

Zeffane, Rachid and Rashid Al Mehairi. 2008. Exploring The Differential Impact of Job Statis Faction on Employee Attendance and Conduct : The Case of Utility Company in The United Arab Emirates. Journal of Employee Relations. Vol. 30, No.3, pp : 237-250, October 201. 